\title{
The effectiveness and safety study of topical corticosteroids for psoriasis in adolescent and adult population treatment
}

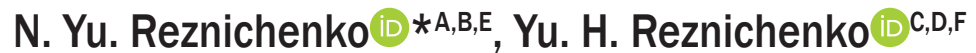

Zaporizhzhia State Medical University, Ukraine

A - research concept and design; B - collection and/or assembly of data; C - data analysis and interpretation; D - writing the article; $\mathrm{E}$ - critical revision of the article; $\mathrm{F}$ - final approval of the article

Key words: psoriasis, topical corticosteroids, life quality.

\section{Zaporozhye}

medical journal

2020; $22(6), 828-832$

*E-mail:

nreznichenkog@gmail. com
Aim: to determine the efficacy and safety of clobetasol propionate compared with fluticasone propionate in the form of ointment for the treatment of psoriasis patients.

Materials and methods. A total of 65 psoriasis patients were included in the study, 40 healthy individuals were included in the control group, all aged 14 to 65 . Psoriasis patients were divided into 2 therapeutic groups: I - received topical treatment with fluticasone propionate; II - with clobetasol propionate. The severity of psoriasis was assessed by BSA and PASI index. Assessment of itching severity was carried out by a ten-point visual analogue scale. The quality of life was assessed according to the Ukrainian version of DLQI questionnaire.

Results. PASI index averaged $16.50 \pm 0.65$ points, and BSA index was $9.30 \pm 0.94 \%$ in the examined patients before the treatment. On average, the DLQI index in patients with psoriasis before the treatment was $13.80 \pm 0.27$ points. PASI index was lower in psoriasis patients treated with clobetasol propionate compared with the therapeutic group I patients. The $\triangle P A S I$ indicator $(\%)$ at the end of the treatment was significantly lower in patients from the I therapeutic group, compared with the group of patients who used clobetasol propionate for treatment of psoriasis. Patients who used clobetasol propionate had lower scores for pruritus and excoriation at the end of the treatment compared with patients from the I therapeutic group. The DLQI index at the end of the treatment was significantly higher in the I therapeutic group compared with its values in patients who used clobetasol propionate in the complex treatment.

Conclusions. The use of topical corticosteroid clobetasol propionate in the form of ointment is the effective treatment for psoriasis, which causes a rapid regression of psoriatic rashes, a decrease in PASI and BSA indices, a decrease in pruritus and its objective signs, and indirectly improves the quality of life.
Киючові слова: псоріаз, топічні кортикостероїди, якість життя.

Запорізький медичний журнал. 2020. T. 22, № 6(123) C. 828-832

\section{Аослідження ефективності та безпечності застосування топічних кортикостероїдів у Аікуванні псоріазу в підмітків і дорослих}

\section{Н. Ю. Резніченко, Ю. Г. Резніченко}

Мета роботи - визначення ефективності та безпечності застосування клобетазолу пропіонату порівняно з флутиказону пропіонатом у формі мазі під час лікування хворих на псоріаз.

Матеріали та методи. У дослідження залучили 65 хворих на псоріаз, у контрольну групу -40 здорових осіб віком від 14 до 65 років. Хворих на псоріаз поділили у 2 терапевтичні групи: I - пацієнти, які отримували топічне лікування флутиказону пропіонатом; II - клобетазолу пропіонат. Тяжкість псоріазу оцінювали за індексами BSA, PASI. Тяжкість свербежу шкіри визначали за десятибальною візуальною аналоговою шкалою. Якість життя оцінювали за українською версією опитувальника DLQI.

Результати. У хворих, яких обстежили, до початку лікування індекс PASI в середньому становив 16,50 \pm 0,65 бала, індекс BSA $-9,30 \pm 0,94 \%$. У середньому індекс DLQI у хворих на псоріаз до початку лікування становив 13,80 $\pm 0,27$ бала. Індекс PASI був нижчим у хворих на псоріаз, які застосовували клобетазолу пропіонат, порівняно з I терапевтичною групою пацієнтів. Показник $\triangle \mathrm{PASI}$ (\%) наприкінці лікування вірогідно нижчий у пацієнтів I терапевтичної групи порівняно з групою хворих, які в комплексній терапії псоріазу використовували клобетазолу пропіонат. Пацієнти, які застосовували клобетазолу пропіонат, наприкінці лікування мали нижчі бальні оцінки свербежу та екскоріацій порівняно з особами з I терапевтичної групи. Індекс DLQI наприкінці лікування вірогідно вищий у I терапевтичній групі хворих порівняно з його значеннями в пацієнтів, які в комплексному лікуванні застосовували клобетазолу пропіонат.

Висновки. Застосування топічного кортикостероїда клобетазолу пропіонату у формі мазі - ефективний метод лікування псоріазу, що сприяє швидкому регресу псоріатичних висипань, зниженню індексів PASI, BSA, зменшенню відчуття свербежу та його об'єктивних ознак, а отже опосередковано зумовлює поліпшення якості життя.
Киючевые слова: псориаз, топические кортикостероиды, качество жизни.

Запорожский медицинский журнал 2020. T. 22, № 6(123) C. 828-832

\section{Исследование эффективности и безопасности применения топических кортикостероидов в кечении псориаза у подростков и взрослых}

\section{Н. Ю. Резниченко, Ю. Г. Резниченко}

Цель работы - определение эффективности и безопасности применения клобетазола пропионата по сравнению с фрлутиказона пропионатом в форме мази при лечении больных псориазом.

Материалы и методы. В исследование включили 65 больных псориазом, в контрольную группу - 40 здоровых лиц в возрасте от 14 до 65 лет. Больных псориазом поделили в 2 терапевтические группы: I - пациенты, получавшие топическое 
лечение фрлутиказона пропионатом; II - лечение клобетазола пропионатом. Оценивали тяжесть псориаза по индексу BSA, индексу PASI. Тяжесть зуда определяли по десятибалльной визуальной аналоговой шкале. Качество жизни оценивали по украинской версии опросника DLQI.

Результаты. У обследованных больных до начала лечения индекс PASI в среднем составлял 16,5 \pm 0,65 балла, индекс BSA - 9,30 \pm 0,94 \%. В среднем индекс DLQI у больных псориазом до начала лечения составлял 13,80 $\pm 0,27$ балла. Индекс PASI был ниже у больных псориазом, получавших клобетазола пропионат, по сравнению с I терапевтической группой пациентов. Показатель $\triangle \mathrm{PASI}(\%)$ в конце лечения достоверно ниже у пациентов I терапевтической группы по сравнению с группой больных, которые в комплексной терапии псориаза использовали клобетазола пропионат. Пациенты, применявшие клобетазола пропионат, в конце лечения имели более низкие балльные оценки зуда и экскориаций по сравнению с больными I терапевтической группы. Индекс DLQI в конце лечения достоверно выше в I терапевтической группе больных по сравнению с его значениями у пациентов, которые в комплексном лечении применяли клобетазола пропионат.

Выводы. Применение топического кортикостероида клобетазола пропионата в форме мази - эффективный метод лечения псориаза, который вызывает быстрый регресс псориатических высыпаний, снижение индексов PASI, BSA, уменьшение зуда и его объективных признаков и, таким образом, косвенно способствует улучшению качества жизни.

To date, psoriasis is one of the most actual medical and social problems [1,2]. The effect of psoriasis is a significant decrease in the quality of life, disability of patients, difficulties in starting a family and deterioration of the family relationships, significant psychological discomfort $[3,4]$

The prevalence of psoriasis in the population is high and composes from 0.1 to $3.0 \%$ of the world's population, according to various authors. In the general structure of the incidence of dermatological diseases, the proportion of patients with psoriasis is 8-15\% [5,6]. In Ukraine, psoriasis has increased in recent years $[5,6]$. There is also an increase in the number of patients with severe forms of psoriasis, which are resistant to various therapies [7]. This happens due to many factors, including urbanization and the negative impact of the environment, especially in large industrial cities.

The treatment of psoriasis requires some algorithms that lead to regression of rash without causing systemic or topical side effects [8-10]. Standard treatment of psoriasis includes diet, sedatives, detoxifying and hypo-sensitizing medicines, hepatoprotectors, vitamins (A, E, C, group B), nonspecific stimulating therapy, physiotherapy, as well as methotrexate, leflunamide and immune biologic therapy in severe cases [11-13]. Topical treatment of psoriasis consists of topical corticosteroids and, in some cases, in combination of topical corticosteroids with keratolytics [14-16].

The primary choice of topical corticosteroids in the treatment of progressive stage of psoriasis is important due to their marked anti-inflammatory, antipruritic, antiproliferative and immunosuppressive effects [17]. According to the European Classification of Topic Corticosteroid Activity, first proposed by J. A. Miller, D. D. Munro, four classes of topical corticosteroids are distinguished: I - with the lowest activity, IV - with the highest activity [18]. However, today there is a lot of debate about the choice of the most optimal topical corticosteroid. Some authors point to the priority of using short courses of high potency topical corticosteroids over long-term use of low potency class I topical corticosteroids [19]. Other researchers, on the contrary, say that moderate and low potency topical corticosteroids are optimal substances for the treatment of psoriasis $[5,20]$.

\section{Aim}

The objective of the study was to determine the effectiveness and safety of the use of clobetasol propionate compared with fluticasone propionate in the form of ointment for the treatment of psoriasis patients in adolescence and adulthood.

\section{Materials and methods}

A total of 65 patients with psoriasis aged 14 to 65 years were included in the study. The control group included 40 healthy individuals of the same age. The recruitment of psoriasis patients and persons from the control group, as well as all the examinations of the enrolled patients, were carried out at the Community Institution "Zaporizhzhia Regional Dermatovenereology Clinical Dispensary" of Zaporizhzhia Regional Council.

Inclusion criteria for participation in the study:

1. Signed informed consent to participate in the study.

2. Male or female aged 14 to 65 years with diagnosis of chronic plaque psoriasis (for therapeutic groups) or without dermatological pathology (for the control group).

3. Consent to use highly effective methods of contraception throughout the study.

4. Patients who are not candidates for systemic psoriasis therapy.

Exclusion criteria for participation in the study:

1. The presence of active dermatological diseases, in addition to psoriasis, which may affect the results of the study in the opinion of an investigator.

2. The presence of other uncontrolled diseases that may affect the study results or lead to the risk of participation in the study.

3. Surgery performed within 12 weeks prior to enrollment in the study or planning of surgery during the study.

4. The presence or a history of oncological diseases.

5. Pregnancy or lactation in females.

6. Chronic alcohol or drug abuse.

7. The use of medications that may affect the study results within 12 weeks before inclusion in the study in the opinion of the investigator.

8. The presence of hypersensitivity to any component of the topical agents used in the study.

Psoriasis patients were randomized into 2 therapeutic groups: Group I - 28 patients who received topical treatment with fluticasone propionate; Group II - 37 people who received topical treatment with clobetasol propionate.

The prevalence of psoriatic process was assessed using a standardized BSA index, which determined the percentage of psoriasis-affected body area. The severity of psoriasis was assessed according to PASI index, which 
determined the severity of peculiar manifestations (erythema, infiltration and scaling) and area of involvement (head, upper limbs, trunk, lower extremities). Changes in PASI index during treatment are an objective indicator of treatment outcomes. Therefore, in order to evaluate the effectiveness of the proposed treatment, we determined percentage decrease in PASI index ( $\triangle \mathrm{PASI}, \%), \triangle \mathrm{PASI}-50$ (which corresponds to a decrease in PASI index by $50 \%$ ).

The severity of itching was assessed on a ten-point visual analog scale, with 0 points being the total absence of itching and 10 points being its maximum intensity. In addition, objective itching features, such as excoriations and nail plate changes (polished surface, thinning of the free edge) were evaluated. Each of the objective signs of itching was evaluated on a point scale, where 0 points was the absence of a sign, 1 point - its weak expression, 2 points - moderate sign, 3 points - a significant severity.

Assessment of the life quality in patients with psoriasis was conducted according to Ukrainian version of DLQI questionnaire. Changes in DLQI index during treatment are an objective indicator of treatment outcomes. Therefore, to evaluate the effectiveness of treatment we determined the percentage decrease in DLQI index ( $\triangle \mathrm{DLQI}, \%)$ [1].

All obtained digital data were processed statistically. A paired Student's criterion or Wilcoxon's Rank-Sum criterion was used to compare the pre- and post-treatment group scores depending on the normality of the differences distribution. The normality of the data distribution was checked using the Shapiro-Wilk test at a significance level of 0.01 . When using all statistical methods (except the Shapiro-Wilk test), the significance level was 0.05 . Statistical processing of the results was performed using the software package Statistica for Windows 13 (StatSoft Inc., № JPZ804I382130ARCN10-J).

\section{Results}

Before the treatment, PASI index averaged $16.50 \pm 0.65$ points in the examined patients, and BSA index was $9.30 \pm 0.94 \%$.

In contrast to healthy individuals, in some patients with psoriasis, the clinical examination revealed objective signs of itching, such as excoriation and changes in the nail plates (polished surface, thinning of the free margin). The score of changes in the nail plates before the treatment averaged $0.23 \pm 0.04$ points, and the score of excoriations was $0.33 \pm 0.07$ points. In addition, patients with psoriasis assessed the intensity of itching on a 10-point visual analog scale. On average, they rated itching at $4.57 \pm 0.54$ points.

Deterioration of skin in general, the presence of skin rash and itching led to a decrease in the quality of life in psoriasis patients. This caused an increase in DLQI index. The average DLQI index in patients with psoriasis before the treatment was $13.80 \pm 0.27$ points.

We analyzed the study results at the end of the treatment course. First of all, good tolerability of fluticasone propionate and clobetasol propionate should be noted. The course of topical corticosteroids did not exceed 10 days, and during this time, neither local nor systemic side effects were noted. Although it should be emphasized that long-term and intensive treatment with highly active corticosteroids can lead to dilation of superficial blood vessels, thinning of skin, formation of stretch marks, hypertrichosis and other adverse effects. Therefore, the data obtained have proved the safety of fluticasone propionate and clobetasol propionate application during 10 days.

The use of clobetasol propionate caused rapid regression of psoriatic lesions. The area of the affected skin and PASI index changed in patients with psoriasis during treatment. The results of skin assessment are given in Table 1. This table shows, that there was a significant decrease in BSA and PASI indices after treatment in patients from both treatment groups, compared with the group of patients before the treatment. These data indicate an improvement in clinical picture of the disease, reduction of skin lesions, regression of erythema, infiltration and peeling. It should be noted that PASI index was lower in psoriasis patients who received clobetasol propionate, compared with therapeutic group I of patients. The rate of $\triangle \mathrm{PASI}(\%)$ at the end of the treatment was significantly lower in patients from therapeutic group I, compared with the group of patients who used clobetasol propionate in therapy of psoriasis.

In addition, there was a higher percentage of patients who reached PASI 50 (patients in whom PASI index decreased by $50 \%$ ) in the group of patients who used clobetasol propionate, compared with therapeutic group I of patients. These data have proved the positive clinical effect of clobetasol propionate in the treatment of psoriasis.

The decrease in skin itching and its objective signs (changes in the nail plates and the presence of excoriations) were fixed after treatment in patients with psoriasis (regardless of the therapeutic group) (Fig. 1). We obtained a significant difference in the score of itching before the treatment and after its completion between the patients of both study groups. When comparing the scores of itching and the severity of its objective signs in patients from different therapeutic groups after treatment, we have found that patients who used clobetasol propionate had lower scores of itching and excoriation, compared with subjects from therapeutic group I.

We also evaluated the effect of clobetasol propionate on the quality of life in patients with psoriasis. Table 1 shows, that in patients from both therapeutic groups on the treatment, DLQI index was significantly reduced, which indicates an improvement in their quality of life compared with patients before the treatment. It should be noted that DLQI index at the end of the treatment was significantly higher in the therapeutic group I patients, compared with its values in patients who used clobetasol propionate. In addition, we have found a significant difference in DLQI (\%) between therapeutic groups of patients I and II. These data once again emphasize the effectiveness of clobetasol propionate in the treatment of patients with psoriasis. The results suggest a significant positive effect from the use of topical corticosteroid clobetasol propionate for both - reduction of clinical manifestations of psoriasis and indirect improvement in the quality of life.

\section{Discussion}

According to studies conducted by some authors [5,16,20], mometasone furoate, hydrocortisone hydroxybutyrate, methylprednisolone aceponate and fluticasone (topical cor- 
ticosteroids of low and moderate activity) are recognized as optimal for the treatment of psoriasis. This is due to the lower incidence of side effects when using topical corticosteroids of low and moderate activity. The difference in the strength of action is associated with different ways of implementing the anti-inflammatory activity of the topical steroid: the extragenomic pathway (transactivation), carried out by binding to DNA and activating the synthesis of anti-inflammatory proteins; and extragenomic pathway, carried out by interacting with transcription factors and reducing the synthesis of pro-inflammatory proteins $[5,19]$. Some authors $[5,19,20]$ consider the extragenomic pathway to be preferable due to low possibility of side effects. At the same time, Ya. F. Kutasevich et al. [5] found that topical low-potency corticosteroids were most active in inhibiting the synthesis of pro-inflammatory cytokines. The authors noted the fact that topical low-potency corticosteroids (mometasone furoate, fluticasone propionate) had minimal systemic absorption, predominantly extragenomic mechanism of action, minimal atrophogenic effect, optimal efficacy-to-safety ratio. High therapeutic efficacy of these corticosteroids was observed in $90.6 \%$ of patients [5].

However, the effect of the using topical corticosteroids of low and medium strength occurs much later compared to high-strength topical corticosteroids. An extremely important point in order to avoid side effects from the use of topical corticosteroids with high activity is strict adherence to the instructions for the drug. According to Ukrainian and International recommendations [19], it is restricted to apply highly active topical corticosteroids to large areas of skin, to areas with thin skin (face, genitals, skin folds), and during a prolonged course (more than 10 days). We recommended the use of clobetasol propionate during 10 days on limited areas of the skin in our clinical study. Thanks to such measures, no side effects were noted in any patient.

This proves the safety of the use of topical corticosteroids with high activity when applying in short courses. A significant decrease in PASI and BSA indices is the evidence of greater efficacy of clobetasol propionate compared with topical corticosteroids of lower strength. Our clinical study has shown that the rate of $\triangle \mathrm{PASI}(\%)$ at the end of the treatment was significantly lower in patients who used fluticasone propionate as compared with the group of patients who used clobetasol propionate. The same tendency was fixed for reduction of itching. These data have shown that short courses of high potency topical corticosteroids are safe and more effective that the use of fluticasone propionate.

\section{Conclusions}

1. The use of clobetasol propionate for psoriasis treatment caused significant decrease in PASI index. The rate of $\triangle \mathrm{PASI}(\%)$ at the end of the treatment was significantly higher in patients who used clobetasol propionate, compared with the group of patients who used fluticasone propionate.

2. Patients with psoriasis who used clobetasol propionate had lower scores of itching and excoriation compared with subjects who used fluticasone propionate.

3. DLQI index at the end of the treatment was significantly higher in therapeutic group using fluticasone propionate compared with its values in patients who used clobetasol propionate.
Table 1. PASI, BSA and DLQI indices in patients with psoriasis during treatment

\begin{tabular}{|c|c|c|c|}
\hline \multirow[t]{2}{*}{ Indices, units } & \multirow{2}{*}{$\begin{array}{l}\text { Patients } \\
\text { before } \\
\text { treatment }\end{array}$} & \multicolumn{2}{|l|}{ Patients after treatment } \\
\hline & & $\begin{array}{l}\text { therapeutic group I } \\
\text { (who used fluticasone } \\
\text { propionate) }\end{array}$ & $\begin{array}{l}\text { therapeutic group II } \\
\text { (who used clobetasol } \\
\text { propionate) }\end{array}$ \\
\hline PASI index, scores & $16.50 \pm 0.65$ & $10.7 \pm 1.0^{*}$ & $8.4 \pm 0.9^{*}$ \\
\hline$\triangle \mathrm{PASI}, \%$ & & $57.5 \pm 2.5$ & $65.4 \pm 2.1^{\#}$ \\
\hline$\triangle \mathrm{PASI}>50, \%$ & & 61.1 & 69.9 \\
\hline BSA index, $\%$ & $9.30 \pm 0.94$ & $4.20 \pm 0.62^{*}$ & $2.70 \pm 0.67^{*}$ \\
\hline DLQI index, scores & $13.80 \pm 0.27$ & $10.50 \pm 0.31^{*}$ & $8.90 \pm 0.23^{\star \#}$ \\
\hline$\triangle \mathrm{DLQ}, \%$ & & $31.3 \pm 1.7$ & $38.7 \pm 1.9^{\#}$ \\
\hline
\end{tabular}

*: significant difference $(P<0.05)$ when compared with the corresponding indicators in the group of patients before the treatment; \#: significant difference $(P<0.05)$ when compared with the corresponding indicators in therapeutic group I after the treatment.

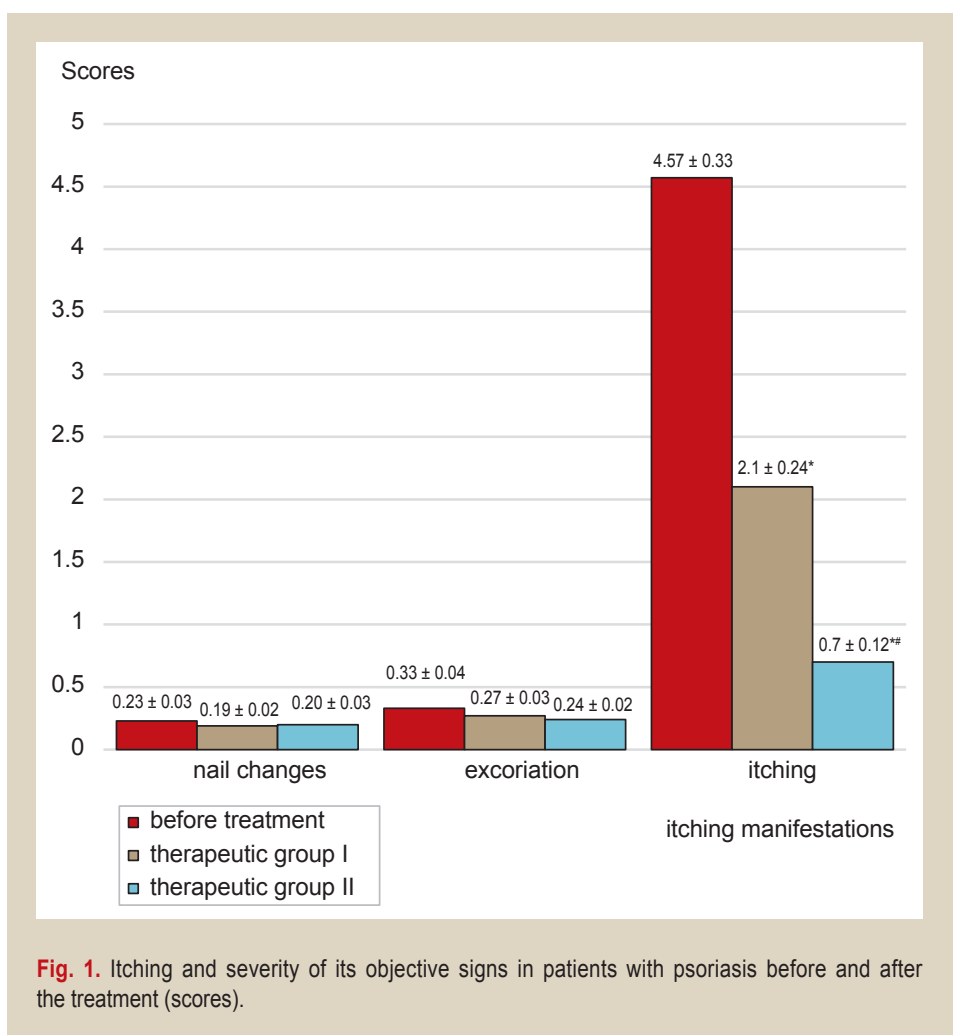

4. The use of the topical corticosteroid clobetasol propionate in the form of ointment is an effective treatment for psoriasis, which caused a rapid regression of psoriatic rash, reduced PASI and BSA indices, decreased itching and its objective symptoms, and indirectly improved the quality of life.

Prospects for further research. Further research will be devoted to comparison of safety and efficacy of topical corticosteroids with different potency for allergic dermatological diseases. The practical significance of the study is to expand the use of topical corticosteroids with high potency in the treatment of patients with psoriasis.

\section{Funding}

The work was a fragment of the comprehensive research work of Zaporizhzhia State Medical University “Development of methods of therapy and prevention of relapses of chronic dermatoses and sexually transmitted diseases, taking into account the peculiarities of homeostasis of patients and concomitant pathology" (State registration № 0113U000800), 2014-2019. 
Conflicts of interest: authors have no conflict of interest to declare. Конфлікт інтересів: віАсутній.

Надійшла Ао реАакції / Received: 14.06.2020

Після Аоопрацювання / Revised: 05.07.2020

Прийнято Ао Аруку / Accepted: 07.07.2020

Information about the authors:

Reznichenko N. Yu., MD, PhD, DSc, Professor, Associate Professor of the Department of Dermatovenereology and Cosmetology with a Course of Dermatovenereology and Aesthetic Medicine of the Faculty of Postgraduate Education, Zaporizhzhia State Medical University, Ukraine.

ORCID ID: 0000-0002-1401-947X

Reznichenko Yu. H., MD, PhD, DSc, Professor of the Department of Hospital Pediatrics, Zaporizhzhia State Medical University, Ukraine.

ORCID ID: $\underline{0000-0003-15-34-0326}$

\section{Відомості про авторів:}

Резніченко Н. Ю., А-р меА. наук, Аоцент, професор каф. Аерматовенерології та косметології з курсом Аерматовенерології та естетичної медицини ФПО, Запорізький Аержавний меАичний університет, Україна.

Резніченко Ю. Г., А-р меА. наук, професор каф. госпітальної педіатрії, Запорізький Аержавний медичний університет, Україна.

\section{Сведения об авторах:}

Резниченко Н. Ю., А-р меА. наук, Аоцент, профессор каф. дерматовенерологии и косметологии с курсом Аерматовенерологии и эстетической медицины ФПО, Запорожский государственный медицинский университет, Украина.

Резниченко Ю. Г., А-р меА. наук, профессор каф. госпитальной педиатрии, Запорожский государственный меАицинский университет, Украина.

\section{References}

[1] Smith, C. H., Jabbar-Lopez, Z. K., Yiu, Z. Z., Bale, T., Burden, A. D. Coates, L. C., Cruickshank, M., Hadoke, T., MacMahon, E., Murphy, R., Nelson-Piercy, C. Owen, C. M., Parslew, R., Peleva, E., Pottinger, E., Samarasekera, E. J., Stoddart, J., Strudwicke, C., Venning, V. A., Warren, R. B., ... Mohd Mustapa, M. F. (2017). British Association of Dermatologists guidelines for biologic therapy for psoriasis 2017. British Journal of Dermatology, 177(3), 628-636. https://doi.org/10.1111/bjd.15665

[2] Vence, L., Schmitt, A., Meadows, C. E., \& Gress, T. (2015). Recognizing Guttate Psoriasis and Initiating Appropriate Treatment. The West Virginia Medical Journal, 111(4), 26-28.

[3] Kui, R., Gál, B., Gaál, M., Kiss, M., Kemény, L., \& Gyulai, R. (2016). Presence of antidrug antibodies correlates inversely with the plasma tumor necrosis factor (TNF)-a level and the efficacy of TNF-inhibitor therapy in psoriasis. The Journal of Dermatology, 43(9), 1018-1023. https://doi.org/10.1111/1346-8138.13301

[4] Sorensen, E. P., Algzlan, H., Au, S. C., Garber, C., Fanucci, K., Nguyen, M. B., \& Gottlieb, A. B. (2016). Lower Socioeconomic Status is Associated With Decreased Therapeutic Response to the Biologic Agents in Psoriasis Patients. Journal of Drugs in Dermatology, 15(2), 147-153.

[5] Kytasevich, Ya. F., \& Mashtakova, I. A. (2012). Ratsional'nyi vybor topicheskogo steroida [Rational choise of the topical steroid]. Ukrainsky zhurnal dermatolohii, venerolohii, kosmetolohii, (1) 55-58. [in Russian].

[6] Reznichenko, N. (2015). Sovremennye podkhody k lecheniyu i profilaktike obostrenii psoriaticheskoi bolezni [Modern approaches to treatment and prophylaxis of exacerbations of psoriasis]. Dermatovenerologiya. Kosmetologiya, (1), 116-128. [in Russian].

[7] Choi, J. W., Kim, B. R., Seo, E., \& Youn, S. W. (2017). Identification of nail features associated with psoriasis severity. The Journal of Dermatology, 44(2), 147-153. https://doi.org/10.1111/1346-8138.13565

[8] Armstrong, A. W., Siegel, M. P., Bagel, J., Boh, E. E., Buell, M., Cooper, K. D., Callis Duffin, K. Eichenfield, L. F., Garg, A., Gelfand, J. M. Gottlieb, A. B., Koo, J. Y., Korman, N. J., Krueger, G. G., Lebwohl, M. G. Leonardi, C. L., Mandelin, A. M., Menter, M. A., Merola, J. F., Pariser, D. M., ... Van Voorhees, A. S. (2017). From the Medical Board of the National Psoriasis Foundation: Treatment targets for plaque psoriasis. Journal of the American Academy of Dermatology, 76(2) 290-298. https://doi.org/10.1016/.j.jaad.2016.10.017

[9] Berth-Jones, J., Exton, L. S., Ladoyanni, E., Mohd Mustapa, M. F. Tebbs, V. M., Yesudian, P. D., \& Levell, N. J. (2019). British Association of Dermatologists guidelines for the safe and effective prescribing of oral ciclosporin in dermatology 2018. British Journal of Dermatology, 180(6), 1312-1338. https://doi.org/10.1111/bjd.17587

[10] Menter, A., Strober, B. E., Kaplan, D. H., Kivelevitch, D., Prater, E. F., Stoff, B., Armstrong, A. W., Connor, C., Cordoro, K. M., Davis, D. Elewski, B. E., Gelfand, J. M., Gordon, K. B., Gottlieb, A. B., Kavanaugh, A., Kiselica, M., Korman, N. J., Kroshinsky, D., Lebwohl, M. Leonardi, C. L., ... Elmets, C. A. (2019). Joint AAD-NPF guidelines of care for the management and treatment of psoriasis with biologics. Journal of the American Academy of Dermatology, 80(4), 1029-1072. https://doi.org/10.1016/j.jaad.2018.11.057

[11] Di Lernia, V., \& Bardazzi, F. (2016). Profile of tofacitinib citrate and its potential in the treatment of moderate-to-severe chronic plaque psoriasis. Drug Design, Development and Therapy, 10, 533-539. https:// doi.org/10.2147/DDDT.S82599

[12] Elmets, C. A., Lim, H. W., Stoff, B., Connor, C., Cordoro, K. M., Lebwohl, M., Armstrong, A. W., Davis, D., Elewski, B. E., Gelfand, J. M., Gordon, K. B., Gottlieb, A. B., Kaplan, D. H., Kavanaugh, A. Kiselica, M., Kivelevitch, D., Korman, N. J., Kroshinsky, D., Leonardi, C. L., Lichten, J., ... Menter, A. (2019). Joint American Academy of Dermatology-National Psoriasis Foundation guidelines of care for the management and treatment of psoriasis with phototherapy. Journa of the American Academy of Dermatology, 81(3), 775-804. https://doi. org/10.1016/j.jaad.2019.04.042

[13] Gordon, K. B., Strober, B., Lebwohl, M., Augustin, M., Blauvelt, A. Poulin, Y., Papp, K. A., Sofen, H., Puig, L., Foley, P., Ohtsuki, M. Flack, M., Geng, Z., Gu, Y., Valdes, J. M., Thompson, E. H. Z., \& Bachelez, H. (2018). Efficacy and safety of risankizumab in moderateto-severe plaque psoriasis (UltIMMa-1 and UltIMMa-2): results from two double-blind, randomised, placebo-controlled and ustekinumabcontrolled phase 3 trials. The Lancet, 392(10148), 650-661. https://doi. org/10.1016/s0140-6736(18)31713-6

[14] Alinia, H., Moradi Tuchayi, S., Smith, J. A., Richardson, I. M., Bahrami, N., Jaros, S. C., Sandoval, L. F., Farhangian, M. E., Anderson, K. L., Huang, K. E., \& Feldman, S. R. (2017). Long-term adherence to topical psoriasis treatment can be abysmal: a 1-year randomized intervention study using objective electronic adherence monitoring. British Journa of Dermatology, 176(3), 759-764. https://doi.org/10.1111/bjd.15085

[15] Lewis, D. J., Chan, W. H., Hinojosa, T., Hsu, S., \& Feldman, S. R. (2019). Mechanisms of microbial pathogenesis and the role of the skin microbiome in psoriasis: A review. Clinics in Dermatology, 37(2), 160166. https://doi.org/10.1016/i.clindermatol.2019.01.011

[16] Schlager, J. G., Rosumeck, S., Werner, R. N., Jacobs, A., Schmitt, J. Schlager, C., \& Nast, A. (2016). Topical treatments for scalp psoriasis Cochrane Database of Systematic Reviews, (2), Article CD009687. https://doi.org/10.1002/14651858.CD009687.pub2

[17] Sekhon, S., Jeon, C., Nakamura, M., Afifi, L., Yan, D., Wu, J. J., Liao, W. \& Bhutani, T. (2018). Review of the mechanism of action of coal tar in psoriasis. Journal of Dermatological Treatment, 29(3), 230-232. https:// doi.org/10.1080/09546634.2017.1369494

[18] Miller, J. A., \& Munro, D. D. (1980). Topical Corticosteroids: Clinica Pharmacology and Therapeutic Use. Drugs, 19(2), 119-134. https:// doi.org/10.2165/00003495-198019020-00004

[19] Kleyn, E. C., Morsman, E., Griffin, L., Wu, J. J., Cm van de Kerkhof, P., Gulliver, W., van der Walt, J. M., \& Iversen, L. (2019). Review of international psoriasis guidelines for the treatment of psoriasis: recommendations for topical corticosteroid treatments. Journal of Dermatological Treatment, 30(4), 311-319. https://doi.org/10.1080/0 9546634.2019.1620502

[20] Lebwohl, M. G., Sugarman, J. L., Gold, L. S., Pariser, D. M., Lin, T., Pillai, R., Martin, G., Harris, S., \& Israel, R. (2019). Long-term safety results from a phase 3 open-label study of a fixed combination halobetaso propionate $0.01 \%$ and tazarotene $0.045 \%$ lotion in moderate-to-severe plaque psoriasis. Journal of the American Academy of Dermatology, 80(1), 282-285. https://doi.org/10.1016/j.jaad.2018.09.002 